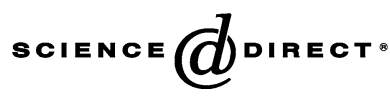

Palaeogeography, Palaeoclimatology, Palaeoecology 221 (2005) 1-6
PALAEO

www.elsevier.com/locate/palaeo

\title{
Seasonal Amazonian rainfall variation in the Miocene Climate Optimum ${ }^{\text {th }}$
}

\author{
Ron J.G. Kaandorp ${ }^{\mathrm{a}, *}$, Hubert B. Vonhof ${ }^{\mathrm{a}}$, Frank P. Wesselingh ${ }^{\mathrm{b}, \mathrm{c}}$, \\ Lidia Romero Pittman ${ }^{\mathrm{d}}$, Dick Kroon ${ }^{\mathrm{a}}$, Jan E. van Hinte ${ }^{\mathrm{a}}$

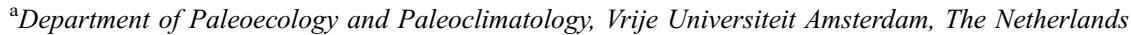 \\ ${ }^{\mathrm{b}}$ Department of Cenozoic Mollusca, Nationaal Natuurhistorisch Museum Naturalis, Leiden, The Netherlands \\ ${ }^{\mathrm{c}}$ Faculty of Biology, University of Turku, Finland \\ dinstituto Geológico Minero y Metalúrgico, San Borja, Lima 12, Peru
}

Received 17 June 2004; received in revised form 23 December 2004; accepted 24 December 2004

\begin{abstract}
Modern and fossil freshwater bivalves from north-eastern Peru are investigated to reconstruct seasonal rainfall patterns in Miocene Amazonia. Oxygen isotope variation in incremental growth bands of fossil bivalves reflects past hydrological conditions in the Miocene Climate Optimum (MCO), when the world was warmer than today. A calibration experiment was conducted on a modern bivalve. Modern river dwelling Triplodon corrugatus shows large amplitudinal changes in $\delta^{18} \mathrm{O}$, which mirror the seasonal variation in rainfall as a result of the annual migration cycle of the Inter Tropical Convergence Zone (ITCZ). Growth incremental oxygen isotope records of Miocene Amazonian Diplodon aff. longulus bivalves show strikingly similar patterns. This suggests that the seasonal migration of the ITCZ and the intensity of the hydrological cycle in the MCO were comparable to today. The implications are that humid climate conditions sufficient to sustain a rainforest ecosystem already existed $\sim 16$ Ma ago.
\end{abstract}

(C) 2005 Elsevier B.V. All rights reserved.

Keywords: Western Amazon Basin; Pebas Formation; Miocene Climate Optimum; Stable isotopes; Bivalves; Precipitation; Seasonal variations

\section{Introduction}

Rainforest systems are sustained by specific environmental conditions characterized by large amounts

\footnotetext{
t5 Oxygen isotope data are archived in Boulder on line at ftp:// ftp.ngdc.noaa.gov/paleo/contributions_by_author/kaandorp2005/.

* Corresponding author. Fax: +31 206462457.

E-mail address: ron.kaandorp@falw.vu.nl (R.J.G. Kaandorp).
}

of rainfall. The Amazonian rainforest is one of the major rainforests in the world and today its rainfall is controlled by a monsoonal system driven by the seasonal migration of the ITCZ (Fig. 1; Marengo, 1998). The climatic oscillation results in a distinct wetdry season cyclicity to which rainforest taxa are strongly adapted. Pollen records show that the rainforest existed in the Miocene (Hoorn, 1994), but it is not clear if environmental conditions were similar to 


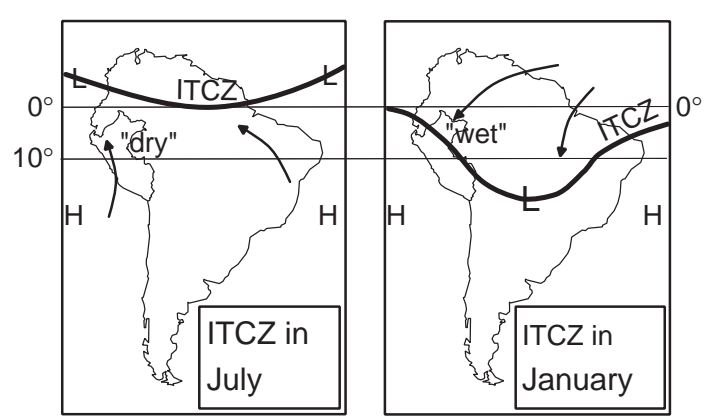

Fig. 1. The ITCZ is a low-pressure band in the tropics where air masses converge from both hemispheres at the boundary between northeasterly and southeasterly trade winds. The ITCZ follows the insolation maxima, migrating to the warmest surface areas throughout the year attaining its northernmost displacement in June-July, and southernmost in December-January. A contracted equatorial continental air mass, together with activity of the eastern Pacific and western Atlantic ITCZ, produces southeastern trade winds over Amazonia. This results in an Amazonian dry period during boreal summer with low river water levels in Peruvian Amazonia in June-September. During austral summer the ITCZ lies south of Amazonia, attracting northern hemisphere northeastern trade winds. Convective activity of an expanded continental air mass over Amazonia in this season causes a wet regime in the region, with maximum precipitation and inundation of várzea in October-May. Northeastern trade winds moving humid air meet the ITCZ in the northwestern part of Amazonia. Elevation of the air mass due to the Andean topography will produce maximum rainfall in April-June. In the central part of the Basin the maximum rain season has a peak during March-May (Marengo, 1998). H stands for atmospheric high pressure, L stands for low pressure.

today. In this paper we show that the seasonal patterns of rainfall in the warmest period of the past 35 million years, $\sim 16 \mathrm{Ma}$ ago, in the middle of the Miocene Climate Optimum (MCO; Flower, 1999; Zachos et al., 1994), were exactly the same as today by using $\delta^{18} \mathrm{O}$ signatures of growth bands in the shells of bivalves.

The largest part of the warm and wet Amazon tropical rainforest is located on terra firme, land that is never inundated. A smaller part, called várzea is permanently or temporarily inundated and consists of floodplains, floating meadows, swamps and flood basin meadows (Hoorn, 1994). Seasonal variation in the amount of precipitation results in several meters of river level variation. This is a precondition for the várzea landscape, with its highly diverse and adapted (semi-) aquatic biota.

The Andean Cordillera in the west of the continent trap atmospheric moisture, which originates from evaporated Atlantic Ocean water, in the Amazon
Basin. Air masses rain out when rising against the eastern Andean slopes (Grootes et al., 1989; Salati and Vose, 1984; Hooghiemstra and Van der Hammen, 1998) providing Amazonia with direct rainfall and runoff water.

Rainfall variation in Amazonia, forced by the seasonal shifting of the ITCZ, is reflected in the oxygen isotopic composition $\left(\delta^{18} \mathrm{O}\right)$ of precipitation (Dansgaard, 1964; Grootes et al., 1989; Rozanski et al., 1993; Global Network for Isotopes in Precipitation and Isotope Hydrology Information System, (available at http://isohis.iaea.org/)). Dry season precipitation in June-August is low; all atmospheric water vapour loss due to precipitation is replenished by means of evapotranspiration. Consequently no depletion of $\delta^{18} \mathrm{O}$ occurs during this period, and rainwater retains an oceanic signature throughout the basin. Convective showers during the wet season (November-April) exceed evapotranspiration by a factor of two to three, depleting the water vapour of its heavy isotopes during transport from Atlantic to Andes (Grootes et al., 1989; Fig. 2). This seasonal behaviour of isotopic composition of precipitation is recorded in Andean ice cores (Grootes et al., 1989; Thompson et al., 1995). At lower altitude temporal and spatial changes of $\delta^{18} \mathrm{O}$ in lakes and rivers are potentially documented in bivalves.

Discrete growth increments of freshwater unionoid shells can be recognized in cross sections and sampled at high-temporal resolution. It has been shown that these growth increments adequately record seasonal variation in the isotopic composition of ambient water (Dettman et al., 1999). For northwestern Amazonia we have shown in a monitoring experiment (Kaandorp et al., 2003) that the bivalve Anodontites trapesialis (Lamarck, 1819) from an Amazon floodplain lake builds its aragonitic shell $\left(\delta^{18} \mathrm{O}_{\mathrm{ar}}\right)$ in isotopic equilibrium with its host water $\left(\delta^{18} \mathrm{O}_{\mathrm{w}}\right)$. The $\delta^{18} \mathrm{O}_{\mathrm{w}}$ is predominantly controlled by rainfall patterns and evaporation. Seasonal temperature variation is negligible. To further support the use of bivalves as recorders of environmental conditions a Triplodon corrugatus (Lamarck, 1819) was collected alive from a clayey substrate in Itaya River $\left(03^{\circ} 47^{\prime} 08^{\prime \prime} \mathrm{S} ; 73^{\circ} 17^{\prime} 08^{\prime \prime} \mathrm{W}\right)$, a small tributary of the Amazon, south of Iquitos, Peru on September 23rd 1998 (Fig. 3). Oxygen isotopes derived from micro-sampled growth increments of $T$. corrugatus 


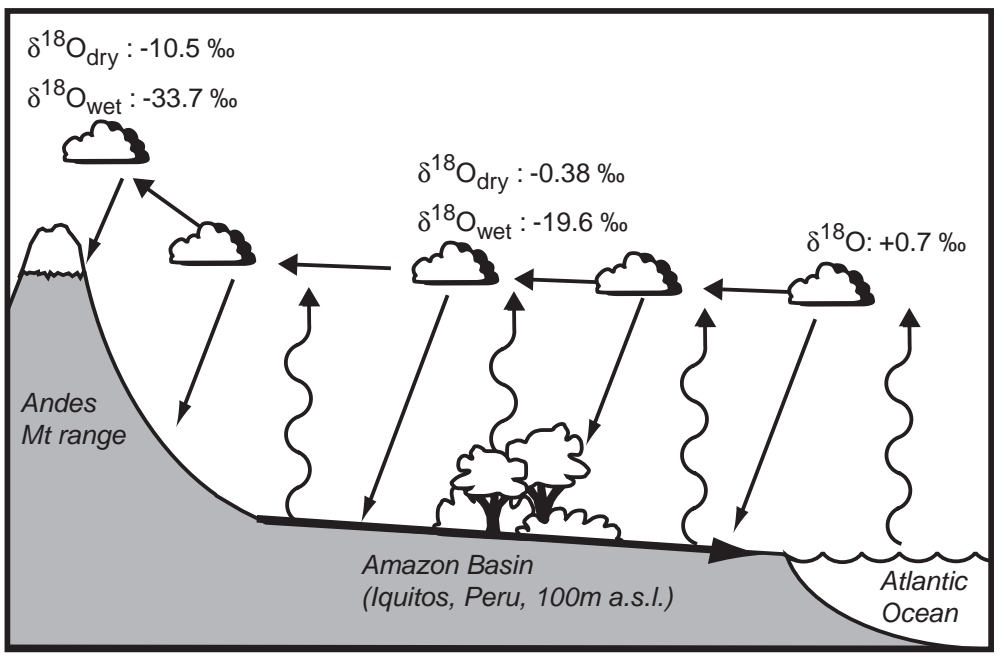

Fig. 2. Seasonal change in oxygen isotope composition of precipitation in Amazonia, modified after Grootes et al., (1989). Precipitation in Iquitos in 1998 and 1999 was measured in this study. Water values $\left(\delta^{18} \mathrm{O}\right)$ are reported against Vienna Standard Mean Ocean Water (V-SMOW).

show a large amplitudinal change from -3.9 to $-10.1 \%$ (Fig. 4a, Supplementary Table 1) representing at least 13 annual cycles each containing a wet season (low $\delta^{18} \mathrm{O}$ values) and a dry season (high $\delta^{18} \mathrm{O}$ values) (Grootes et al., 1989; Kaandorp et al., 2003).

As modern bivalves are evidently good recorders of seasonal patterns, fossil shells are expected to record past seasonality. The extraordinary well-preserved

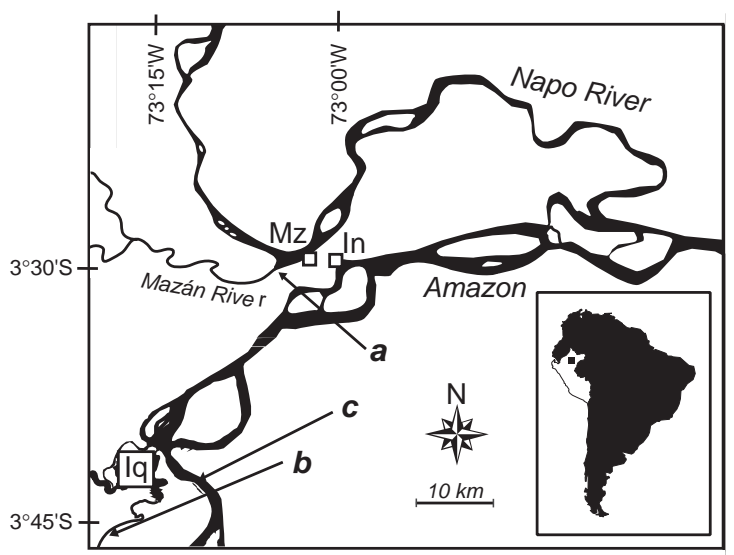

Fig. 3. Location map. a Miocene $D$. aff. longulus bivalves from an outcrop in the right bank of the Napo River at the confluence with the Mazan River. b The sampling site of modern T. corrugatus in the Itaya River. c Monitoring site of $A$. trapesialis bivalves (Kaandorp et al., 2003). The city of Iquitos and the villages of Indiana and Mazán are indicated by Iq, In and Mz, respectively. fossil bivalves from the widely distributed Miocene Pebas Formation in Amazonia (Wesselingh et al., 2002; Vonhof et al., 2003) give an excellent opportunity to reconstruct Miocene seasonal rainfall patterns from stable isotope records from bivalve growth increments. Palynological analyses of Pebas Formation sediments (Hoorn, 1994) provided evidence for the presence of várzea type of biota during the Middle Miocene. The Pebas Formation consists of sands, organic clays, lignites and blue smectite clays found in 3-7 $\mathrm{m}$ thick coarsening-up cycles. Interpolation of pollen ages from nearby Indiana outcrops (Psiladiporites-, Crototricolpites zones, Hoorn, 1994), indicate an age of late Early to Middle Miocene, corresponding to an age of 15-17 Ma on the geological time scale (Berggren et al., 1995). Here we evaluate the climatic conditions that sustained a várzea-type rainforest system in the Miocene Climate Optimum.

Fossil specimens of Diplodon aff. longulus (Conrad, 1874; this form is more convex than D. longulus and is characterized by two or three prominent rounded ventrolateral ridges) were collected from sediments of the Miocene Pebas Formation at the confluence of the Mazán and Napo rivers (coordinates $03^{\circ} 29^{\prime} 58^{\prime \prime} \mathrm{S} ; 73^{\circ} 05^{\prime} 45^{\prime \prime} \mathrm{W}$, Fig. 3). This outcrop is part of the Indiana outcrop group. $\mathrm{Sr}$ isotopes of bivalves from this outcrop indicate a fresh water environment fed by Andean run off (Vonhof et al., 2003). 


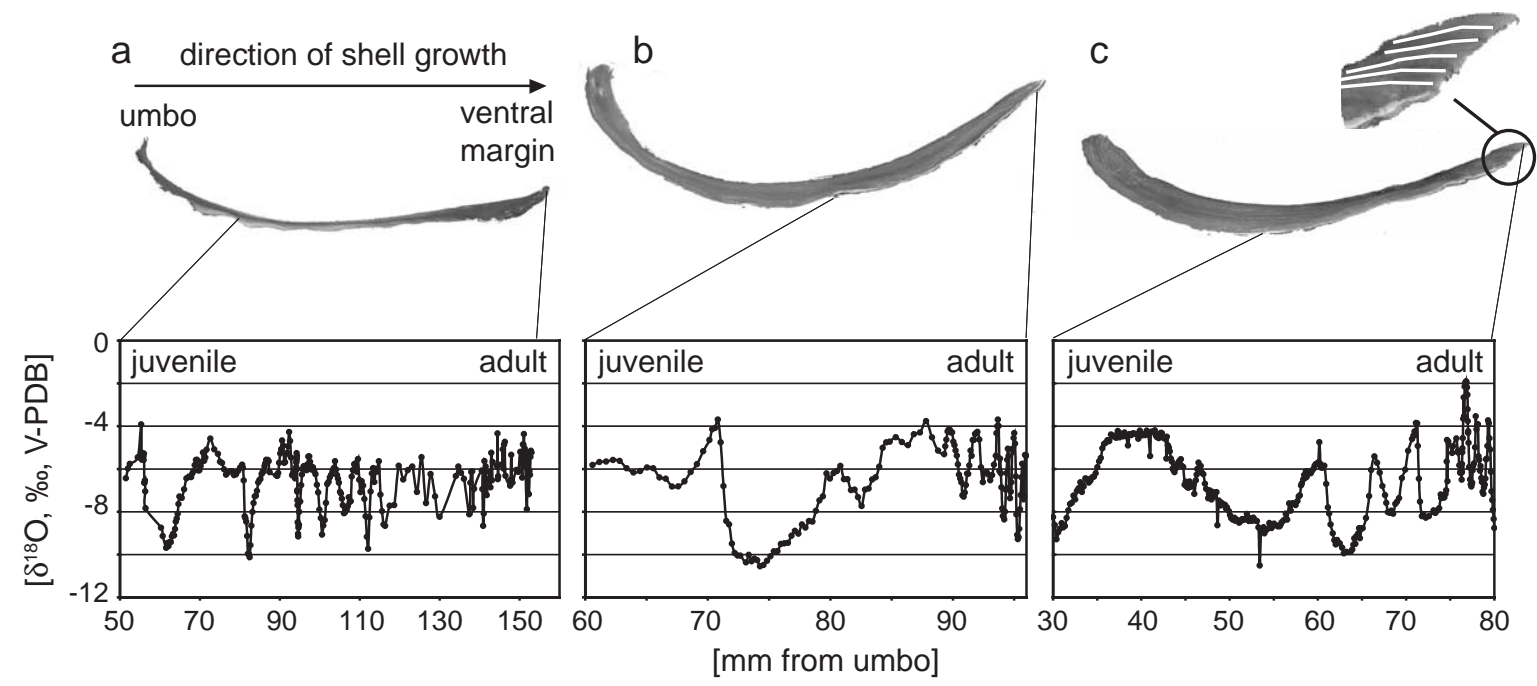

Fig. 4. Oxygen isotope records of samples from bivalves taken along the axis of maximum shell growth. (a) Living T. corrugatus sampled in Itaya River. (b and c) Two fossil D. aff. longulus specimens sampled near Mazán. V-PDB is Vienna PeeDee Belemnite. Growth increments were micro-sampled with a resolution of $\sim 9$ lines per $\mathrm{mm}$. (White lines in the enlargement show examples of micro-sampling milling lines). Powders recovered from each line were used to obtain oxygen stable isotope data $\left(\delta^{18} \mathrm{O}_{\mathrm{ar}}\right)$ performed at Vrije Universiteit Amsterdam on a Finnigan MAT 252 mass spectrometer equipped with an automated preparation line. The long-term reproducibility of a routinely analyzed carbonate standard (NBS 19) is better than $0.09 \%$ for $\delta^{18} \mathrm{O}(1 \mathrm{SD})$. $\delta^{18} \mathrm{O}_{\mathrm{ar}}$ values are reported vs. Vienna-PeeDee Belemnite standard (V-PDB).

The bivalves are excellently preserved. Analyses with a Micro-raman spectrometer show that all bivalves have retained their aragonitic mineralogy. Trace element analyses from similarly well-preserved Pebas Formation bivalves from other localities showed no evidence for diagenetic alteration (Vonhof et al., 1998, 2003). The bivalves were sampled in a single bed containing abundant paired valves, indicating minimal transport prior to deposition.

The oxygen isotope records of the fossil mollusc shells are strikingly similar to modern $A$. trapesialis (Kaandorp et al., 2003) and T. corrugatus (Fig. 4, Supplementary Table 1). Fossil Diplodon bivalves show at least 8 successive $\delta^{18} \mathrm{O}$ cycles with values ranging from -3.7 to $-10.5 \%$ (Fig. $4 \mathrm{~b}$ ) and from -1.9 to $-10.5 \%$ o (Fig. 4c). These data are attributed to dry/wet seasonal change in host water oxygen isotope composition. Diminished growth rates towards the ventral margin, indicated by a condensed annual cyclic signal, are observed in both the modern and fossil shells.

In order to interpret the Miocene $\delta^{18} \mathrm{O}$ signals, we need to assess to what extent the various environ- mental parameters responsible for the oxygen isotope composition of rainwater (Dansgaard, 1964) in the Miocene may have differed from today. These parameters are: latitude, altitude, coastal distance or "continental effect", surface air temperatures, water vapour source and the amount of precipitation. The latitudinal effect has not changed, Amazonia already straddled the equator during the Middle Miocene (Scotese, 2001), and low annual variation of surface air temperature like today is expected. The altitude effect is responsible for the most depleted values of $\delta^{18} \mathrm{O}$ in Amazonian precipitation. Typically the lowest values are found in the Andean ice cores (Grootes et al., 1989; Thompson et al., 1995). However, the contribution of high-altitude precipitation to natural waters in our study area is limited, because rainfall intensity is highest in the Amazonian lowlands. Therefore we expect a possible lower Andean Mountain Range in the Miocene (Steinmann et al., 1999) not to have had much influence on the isotopic composition of waters in our study area. The extremely low isotope values in parts of the molluscs demonstrate that the Andes during the Middle Miocene must have acted as a barrier to 
atmospheric vapour. The mechanism causing the "continental effect" (Dansgaard, 1964; Rozanski et al., 1993) is a gradual removal of moisture by condensation from air masses moving inland, coupled with a preferential removal of heavy isotopes during the condensation process. A longer travel distance would lead to lower $\delta^{18} \mathrm{O}$ of the remaining vapour. Paleogeographical maps of Miocene northern South America (Hoorn et al., 1995) imply no differences in the pathway of vapour travelling from the Atlantic Ocean water to Western Amazonia. Although surface air temperatures on the continent during the Miocene Climate Optimum are not well known, there are good indications that lowlatitude sea surface temperatures (SST) were comparable to today (Savin, 1977; Martinez and del Rio, 2002). At comparable SSTs the amount of evaporated source water should be the same, although the source waters of MCO Amazonian atmospheric moisture might have been slightly more negative than today: MCO calculated global marine water $\delta^{18} \mathrm{O}_{\mathrm{w}}$ value (-0.8\%o, V-SMOW, Lear et al., 2000) is lighter than its modern equivalent $\left(\delta^{18} \mathrm{O}_{\mathrm{w}}=-0.28 \%\right.$ ) , but this is negligible with respect to the observed changes in $\delta^{18} \mathrm{O}$ of the molluscs.

For modern as well as Miocene waters, the amount of precipitation must have been the controlling parameter for seasonal isotopic variation. Based on the observation that cyclicity and absolute values of $\delta^{18} \mathrm{O}$ of Modern and Miocene molluscs are strikingly similar, we conclude that seasonal migration of the ITCZ and the intensity of rainfall in the MCO are comparable to today. Possible higher temperatures during the MCO in our study area are irresolvable in the molluscan $\delta^{18} \mathrm{O}$ records.

Wider implications are that the Amazonian hydrological cycle is most likely not affected by globally warmer climates than today considering potential warming of Earth's climate in future.

The extent of Western Amazonian rainforest in the Middle Miocene was not as large as today, since most of the area was occupied by lakes and wetlands (Nutall, 1990; Wesselingh et al., 2002). Our study shows that climatic conditions required to sustain highly diverse tropical forests and várzea environments existed in the Miocene Climate Optimum.

\section{Acknowledgements}

We are indebted to José and Rusbel Arimuya our boatsmen (Buenavista Nanay), Cahuide del Busto (UNAP, Iquitos) for field assistance, to Wynanda Koot and Bouk Laçet (VU, Amsterdam) for sample preparation and to E.J. Burke (VU Amsterdam) for Raman probe analyses. Kevin S. Cummings (Illinois Natural History Survey) is thanked for the determination of $T$. corrugatus. W. Ricken is thanked for his review and the editorial advice of P. De Deckker is greatly appreciated. This study was funded by WOTRO, the Netherlands Foundation for the Advancement of Tropical Research, residing under the Netherlands Organization for Scientific Research (NWO), under grant W76-195. This is NSG publication $\mathrm{n}^{\circ} 20041204$.

\section{Appendix A. Supplementary data}

Supplementary data associated with this article can be found, in the online version, at doi:10.1016/ j.palaeo.2004.12.024.

\section{References}

Berggren, W.A., Kent, D.V., Swisher III, C.C., Aubry, M.-P., 1995. A revised Cenozoic geochronology and chronostratigraphy. Geochronology Time Scales and Global Stratigraphic Correlation, SEPM Special Publication, vol. 54, pp. 129-212.

Conrad, T.A., 1874. Remarks on the tertiary clay of the upper amazon with descriptions of new shells. Proceedings of the Academy of Natural Sciences, Philadelphia, pp. 25-32.

Dansgaard, W., 1964. Stable isotopes in precipitation. Tellus 16, 436-461.

Dettman, D.L., Reische, A.K., Lohmann, K.C., 1999. Controls on the stable isotope composition of seasonal growth bands in aragonitic fresh-water bivalves (unionoidae). Geochimica et Cosmochimica Acta 63 (7/8), 1049-1057.

Flower, B.P., 1999. Warming without high $\mathrm{CO}_{2}$ ? Nature 399, $313-314$.

Grootes, P.M., Stuiver, M., Thompson, L.G., Mosley-Thompson, E., 1989. Oxygen isotope changes in tropical ice, Quelccaya, Peru. Journal of Geophysical Research 94, 1187-1194.

Hooghiemstra, H., Van der Hammen, T., 1998. Neogene and Quaternary development of the neotropical rain forest: the forest refugia hypothesis, and a literature overview. Earth-science Reviews 44, 147-183.

Hoorn, C., 1994. An environmental reconstruction of the palaeoAmazon River system (Middle to late Miocene, NW 
Amazonia). Palaeogeography, Palaeoclimatology, Palaeoecology $112,187-238$.

Hoorn, C., Guerrero, J., Sarmiento, G., Lorente, M., 1995. Andean tectonics as a cause for changing drainage patterns in Miocene northern South America. Geology 23, 237-240.

Kaandorp, R.J.G., Vonhof, H.B., Del Busto, C., Wesselingh, F.P., Ganssen, G.M., Marmól, A.E., Romero Pittman, L., Van Hinte, J.E., 2003. Seasonal stable isotope variation of the Amazonian fresh water bivalve Anodontites trapesialis. Palaeogeography, Palaeoclimatology, Palaeoecology 194 (4), 339-354.

Lamarck, J.B.P.A. M. le C. de, 1819. Les nayades. Hyrie (HyriaHistoire Naturelle dans Animaux Sans Vertèbres, vol. 6, 1. Musée d'histoire Naturelle, Paris, pp. 81-82.

Lear, C.H., Elderfield, H., Wilson, P.A., 2000. Cenozoic deep-sea temperatures and global ice volumes from $\mathrm{Mg} / \mathrm{Ca}$ in benthic foraminiferal calcite. Science 287, 269-272.

Marengo, J.A., 1998. Climatología de la zona de Iquitos, Perú. In: Kalliola, R., Flores Paitán, S. (Eds.), Geoecología y Desarollo Amazónico, Annales Universitatis Turkuensis, vol. A II 114, pp. $35-57$.

Martínez, S., del Río, C.J., 2002. Late Miocene molluscs from the southwestern Atlantic Ocean (Argentina and Uruguay): a palaeobiogeographic analysis. Palaeogeography, Palaeoclimatology, Palaeoecology 188, 167-187.

Nutall, C.P., 1990. A review of the Tertiary non-marine molluscan faunas of the Pebasian and other inland basins of north-western South America: bulletin of the British Museum (Natural History). Geology Series 45, 165-371.

Rozanski, K., Araguas-Araguas, L., Gonfiantini, R., 1993. Isotopic patterns in modern global precipitation. In: Swart, P.K., et al. (Eds.), Climate Change in Continental Isotopic Records, Geophysical monograph, vol. 78 , pp. 1-36.
Salati, E., Vose, P.B., 1984. Amazon basin: a system in equilibrium. Science 225, 129-138.

Savin, S.M., 1977. The history of the earth's surface temperature during the last 100 million years. Annual Review of Earth and Planetary Sciences 5, 319-355.

Scotese, C.R., 2001. Atlas of earth history. Paleogeography: PALEOMAP project, vol. 1. Arlington, Texas. $52 \mathrm{pp}$.

Steinmann, M., Hungerbühler, D., Seward, D., Winkler, W., 1999. Neogene tectonic evolution and exhumation of the southern Andes: a combined stratigraphy and fission-track approach. Tectonophysics 307, 255-276.

Thompson, L.G., Mosley-Thompson, E., Davis, M.E., Lin, P.-N., Henderson, K.A., Cole-Dai, J., Bolzan, J.F., Liu, K.-B., 1995. Late glacial stage and Holocene tropical ice core records from huascarán, Peru. Science 269, 46-50.

Vonhof, H.B., Wesselingh, F.P., Ganssen, G.M., 1998. Reconstruction of the miocene western amazonian aquatic system using molluscan isotopic signatures. Palaeogeography, Palaeoclimatology, Palaeoecology 141, 85-93.

Vonhof, H.B., Wesselingh, F.P., Kaandorp, R.J.G., Ganssen, G.M., Davies, G.R., van Hinte, J.E., Guerrero, J., Räsänen, M., Romero Pittman, L., Ranzi, A., 2003. Paleogeography of Miocene western Amazonia: isotopic composition of molluscan shells constrains the influence of marine incursions. GSA Bulletin 115 (8), 983-993.

Wesselingh, F.P., Räsänen, M.E., Irion, G., Vonhof, H.B., Kaandorp, R., Renema, W., Romero Pittman, L., Gingras, M., 2002. Lake Pebas: a palaeoecological reconstruction of a Miocene, longlived lake complex in western Amazonia. Cainozoic Research 1, $35-81$.

Zachos, J.C., Stott, L.D., Lohmann, K.C., 1994. Evolution of early Cenozoic marine temperatures. Paleoceanography 9, 353-387. 